\title{
Gastric Cancer pT2 TNM Finding v6
}

National Cancer Institute

\section{Source}

National Cancer Institute. Gastric CancerpT2 TNM Finding v6. NCI Thesaurus. Code C61185.

Gastric cancer with tumor invading the muscularis propria or subserosa. A tumor may penetrate the muscularis propria with extension into the gastrocolic or gastrohepatic ligaments, or into the greater or lesser omentum, without perforation of the visceral peritoneum covering these structures. In this case, the tumor is classified T2. If there is perforation of the visceral peritoneum covering the gastric ligaments or the omentum, the tumor should be classified T3. (from AJCC 6th Ed.) 